WATER-LEVEL MEASUREMENTS FOR SELECTED WELLS IN THE JACKSON, MISSISSIPPI, AREA, OCTOBER 1996-JULY 1997

By Eric W. Strom and William T. Oakley

U.S. GEOLOGICAL SURVEY

Open-File Report 97-561

Prepared in cooperation with the CITY OF JACKSON

Jackson, Mississippi

1997 


\section{U.S. DEPARTMENT OF THE INTERIOR \\ BRUCE BABBITT, Secretary}

\section{U.S. GEOLOGICAL SURVEY}

Gorden P. Eaton, Director

For additional information write to:

District Chief

U.S. Geological Survey 308 South Airport Road

Pearl, Mississippi 39208-6649
Copies of this report can be purchased from:

U.S. Geological Survey

Branch of Information Services Box 25286

Denver, CO 80225-0286 


\section{CONTENTS}

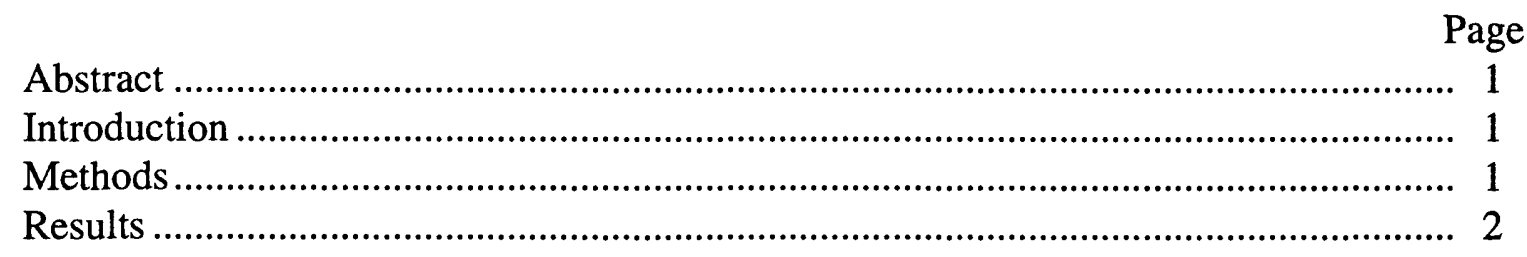

\section{ILLUSTRATIONS}

Figure 1. Map showing location of selected Cockfield and Sparta aquifer wells in the Jackson, Mississippi, area

2-12. Hydrographs of selected wells:

2. M094 5

3. $\mathrm{M} 112$ 6

4. $\mathrm{H} 023$ 7

5. $\mathrm{H} 155$ 8

6. $\mathrm{H} 160$ 9

7. $\mathrm{H} 163$ 10

8. $\mathrm{H} 164$ 11

9. $\mathrm{H} 196$ 12

10. N092 13

11. V029 14

12. W069 15

13. Diagrammatic plot showing the depth of sand and clay intervals for selected well logs, Jackson, Mississippi, area 16

\section{TABLE}

Table 1. Data for selected wells, Jackson, Mississippi, area

\section{CONVERSION FACTORS AND VERTICAL DATUM}

\section{Multiply}

foot

mile
By

0.3048

1.609
To obtain

meter kilometer

Sea level: In this report "sea level" refers to the National Geodetic Vertical Datum of 1929-a geodetic datum derived from a general adjustment of the first-order level nets of both the United States and Canada, formerly called Sea Level Datum of 1929. 


\title{
WATER-LEVEL MEASUREMENTS FOR SELECTED WELLS IN THE JACKSON, MISSISSIPPI, AREA, OCTOBER 1996 - JULY 1997
}

\author{
By Eric W. Strom and William T. Oakley
}

\begin{abstract}
The U.S. Geological Survey collects, on a systematic basis, data needed to determine and evaluate the ground-water resources of the City of Jackson, Mississippi. This report presents water levels measured in selected wells in Hinds and Madison Counties from October 1996 through July 1997 with associated historical water-level data.
\end{abstract}

\section{INTRODUCTION}

The U.S. Geological Survey (USGS) collects, on a systematic basis, data needed to determine and evaluate the ground-water resources of the City of Jackson, Mississippi. The USGS measures water levels in the Cockfield and Sparta aquifers underlying the Jackson, Mississippi, area to assess water-level trends. The purpose of this report is to present water levels measured in selected wells from October 1996 through July 1997 and associated historical water-level data. In addition, the subsurface sand and clay intervals at each well were determined and reported.

\section{METHODS}

Water-level measurements were made in two wells owned by the City of Jackson, Sparta wells M094 and M112. In addition, water-level measurements were made in other wells in the Jackson area (fig. 1) to provide additional information on water-level trends. Measurements were made monthly from October 1996 through July 1997 using a graduated steel tape and battery operated water-level indicator. Hydrographs were constructed (figs. 2-12) using recent and historical water-level measurements. Measurements separated by a time period of greater than 2 years are shown as points on the hydrographs. In pumped wells, the water-level measurements were made after the well pump had been turned off and, generally, water levels were allowed a sufficient 
recovery time. However, short-term fluctuations in water levels can be seen on some hydrographs as dips, probably caused by insufficient recovery time of a pumped well, or caused by drawdown from nearby pumping wells. These dips do not represent the static water level and should generally not be used when evaluating the overall water-level trend.

The subsurface sand and clay intervals at most wells were determined from geophysical logs (fig. 13). For this report, sand is used to indicate aquifer material (fine to coarse sand and gravel); clay is used to indicate confining material (clay and silt). It should be noted that logged intervals may be deeper or shallower than the interval in which the well was screened.

\section{RESULTS}

The results of the water-level measurements made at selected wells in the Cockfield and Sparta aquifers are shown as hydrographs on figures 2-12. Additional information for each well is listed in table 1. All of the hydrographs show an overall decline in water levels since the first measurements were made. The rates of water-level decline were calculated by using the hydrographs of several wells. Rates of water-level decline were determined from hydrographs using static water levels and were not simply the maximum difference in water levels over the period of record, which may not be representative due to nearby pumping wells. For two of the observation wells with the longest period of record, $\mathrm{H} 023$ and $\mathrm{H} 160$, water-level declines at a rate of about 2.5 feet per year in the Sparta aquifer are indicated. For the two northern most measured wells, V029 and W069, water levels declined at a rate of about 3.5 to more than 4 feet per year, respectively; these were the highest calculated rates of water-level decline for the measured wells in the Sparta aquifer. The lowest rates of water-level decline were calculated for wells in the Cockfield aquifer (H155, H196 and N092) and range from about 0.5 to 1.5 feet per year. 
Table 1. Data for selected wells, Jackson, Mississippi, area [Altitude in feet; USGS, U.S. Geological Survey]

\begin{tabular}{llcccl}
\hline Well & Latitude & Longitude & Altitude & Landnet Location & Listed owner \\
\hline H023 & 322304 & 900850 & 315 & T. 06 N., R. 01 E., Sec. 12 & Kenneth Muse \\
H155 & 321951 & 901058 & 330 & T. 06 N., R. 01 E., Sec. 27 & Miss. Geological Survey \\
& & & & & \\
H160 & 322243 & 900739 & 305 & T. 06 N., R. 02 E., Sec. 07 & Colonial Country Club \\
H163 & 322223 & 901328 & 354 & T. 06 N., R. 01 E., Sec. 08 & Tri State Brick \\
& & & & & \\
H164 & 322212 & 900957 & 298 & T. 06 N., R. 01 E., Sec. 11 & Homewood Manor \\
H196 & 322003 & 900925 & 290 & T. 06 N., R. 01 E., Sec. 25 & Miss. Ag Museum \\
& & & & & \\
M094 & 321454 & 901603 & 360 & T. 05 N., R. 01 W., Sec. 26 & Jackson \\
M112 & 321422 & 901801 & 330 & T. 05 N., R. 01 W., Sec. 28 & Jackson \\
N092 & 321752 & 901026 & 271 & T. 05 N., R. 01 E., Sec. 02 & USGS Fairgrounds \\
V029 & 322415 & 900944 & 355 & T. 07 N., R. 01 E., Sec. 35 & Tougaloo College \\
W069 & 322514 & 900809 & 350 & T. 07 N., R. 02 E., Sec. 30 & Ridgeland \\
\hline
\end{tabular}




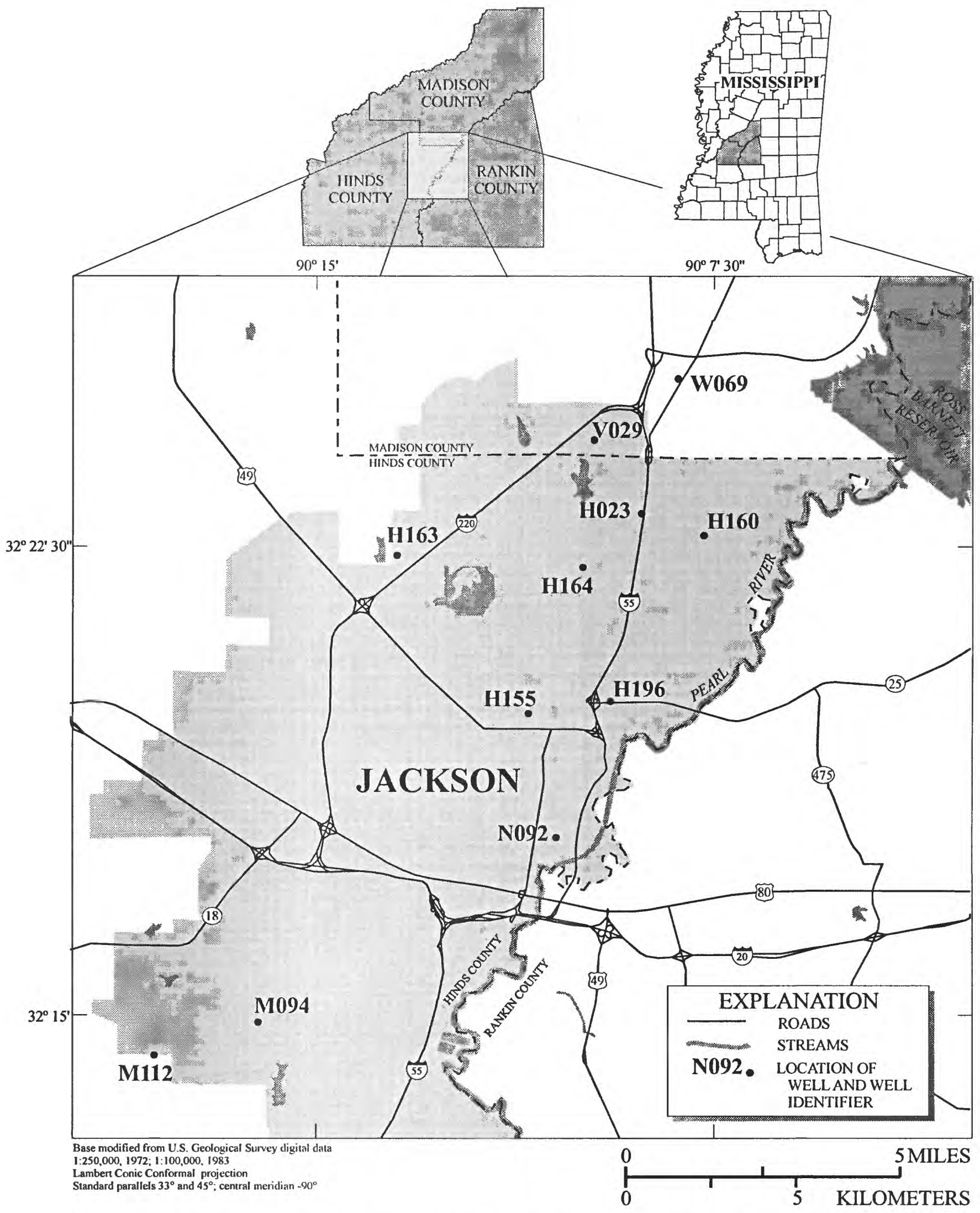

Figure 1. Location of selected Cockficld and Sparta aquifer wells in the Jackson, Mississippi, area. 


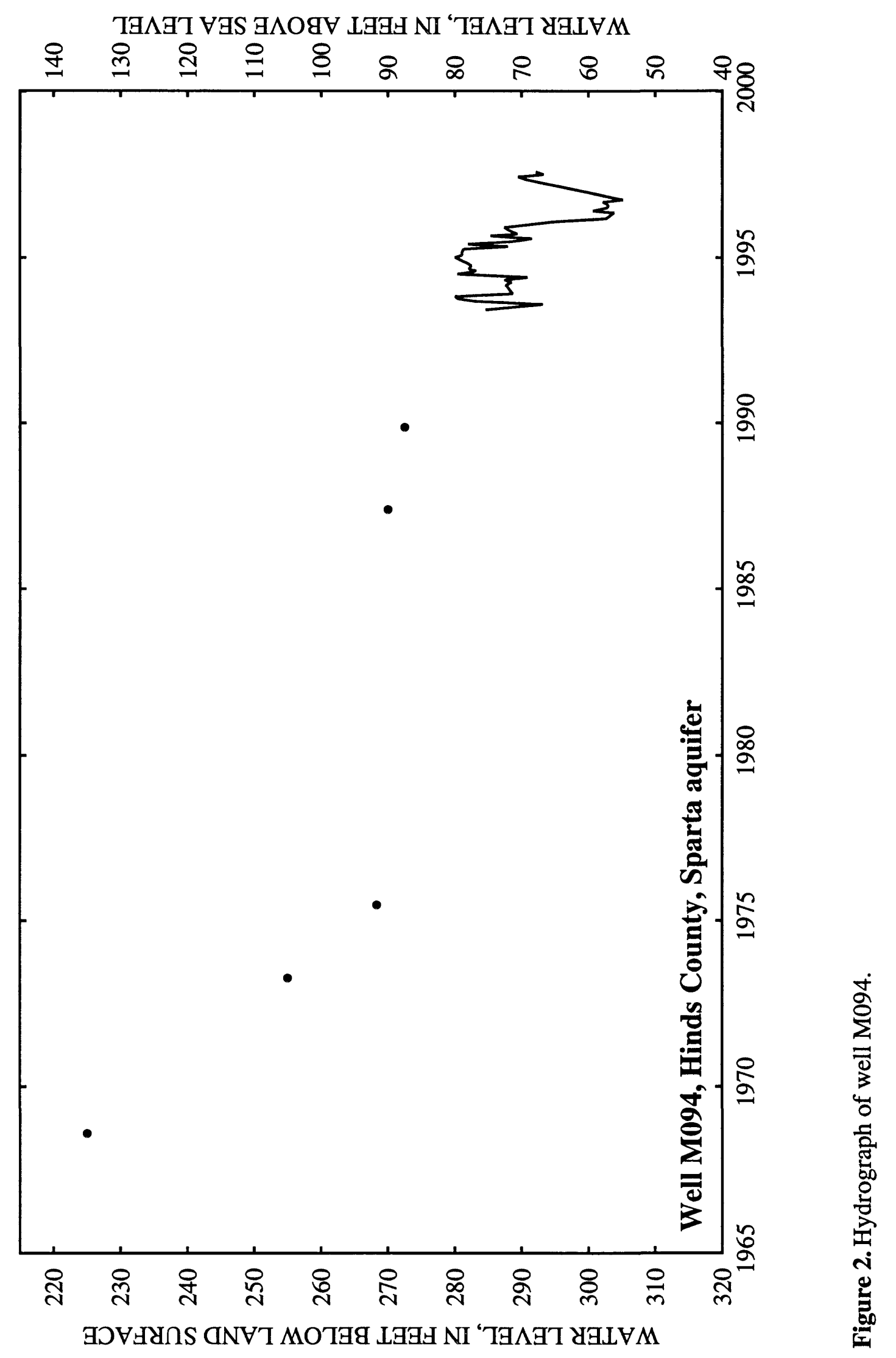




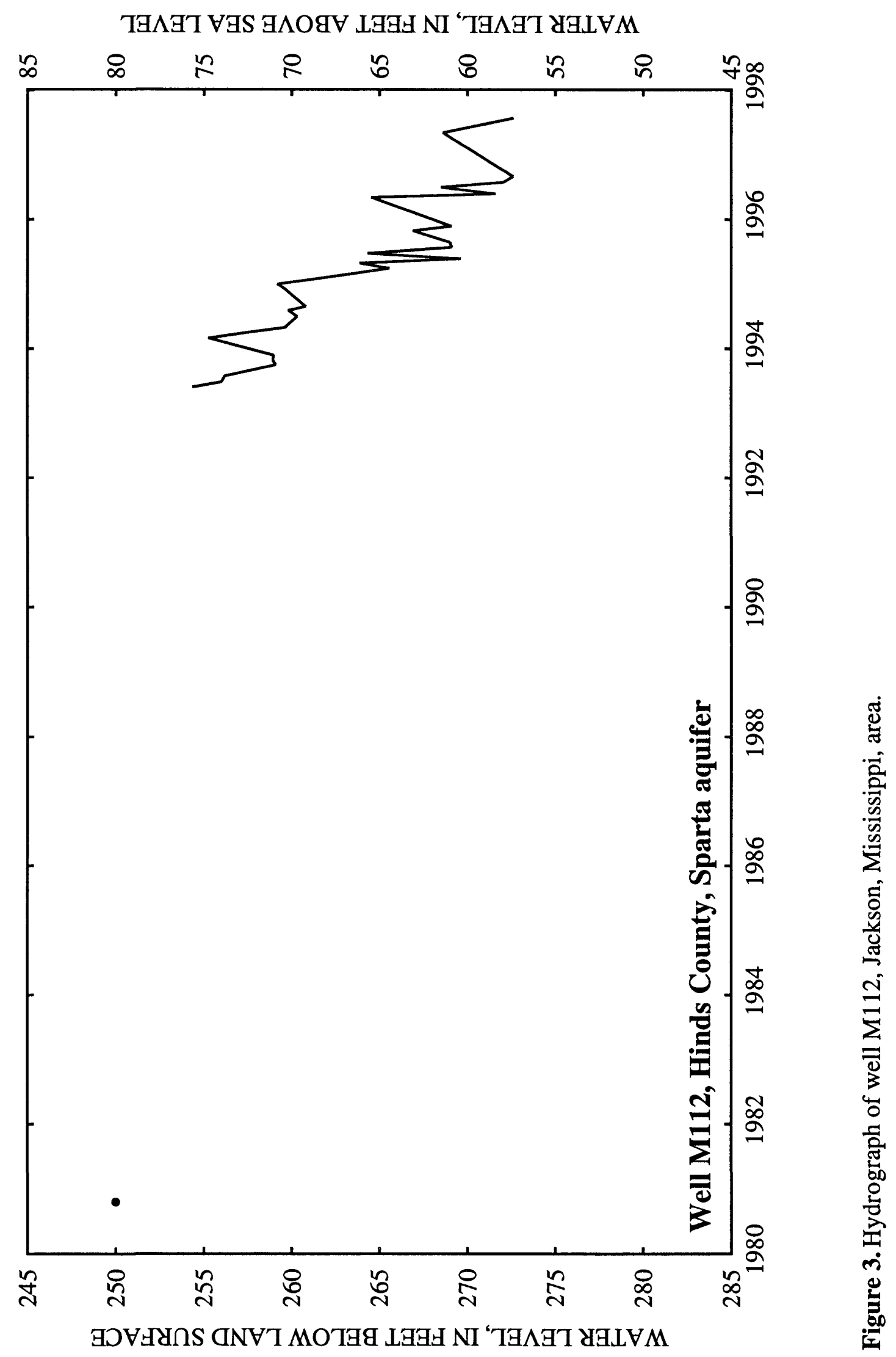




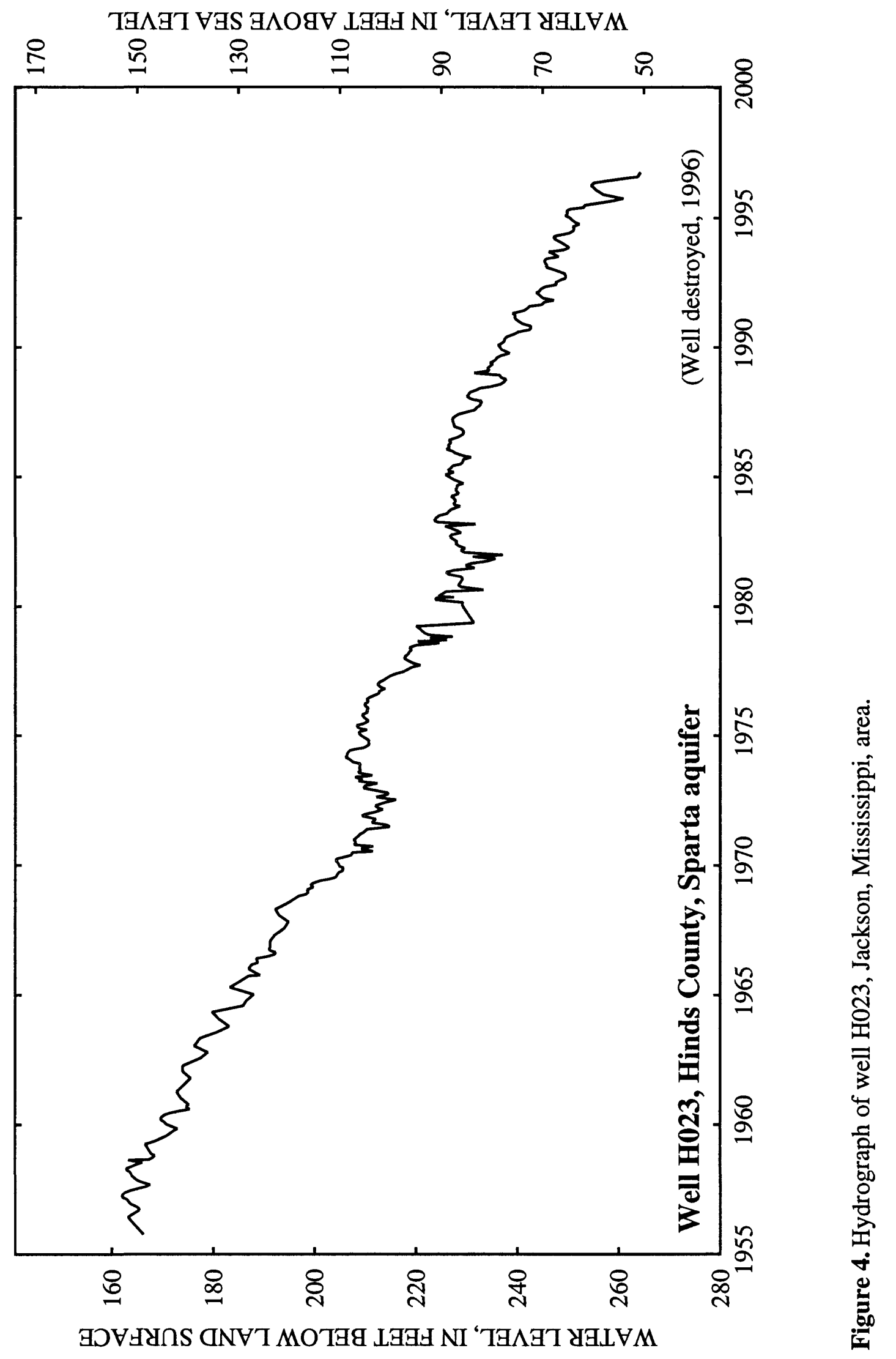




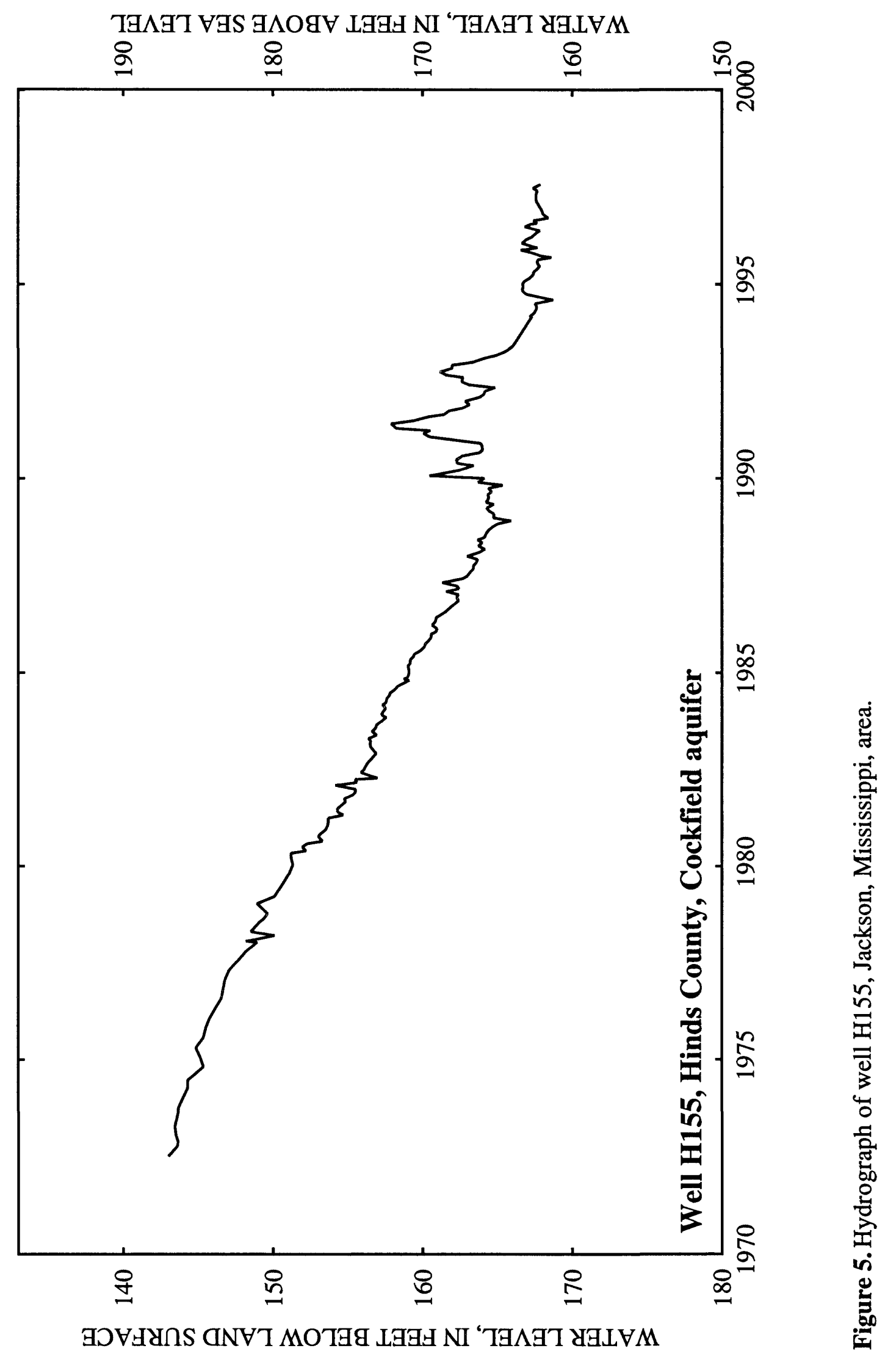




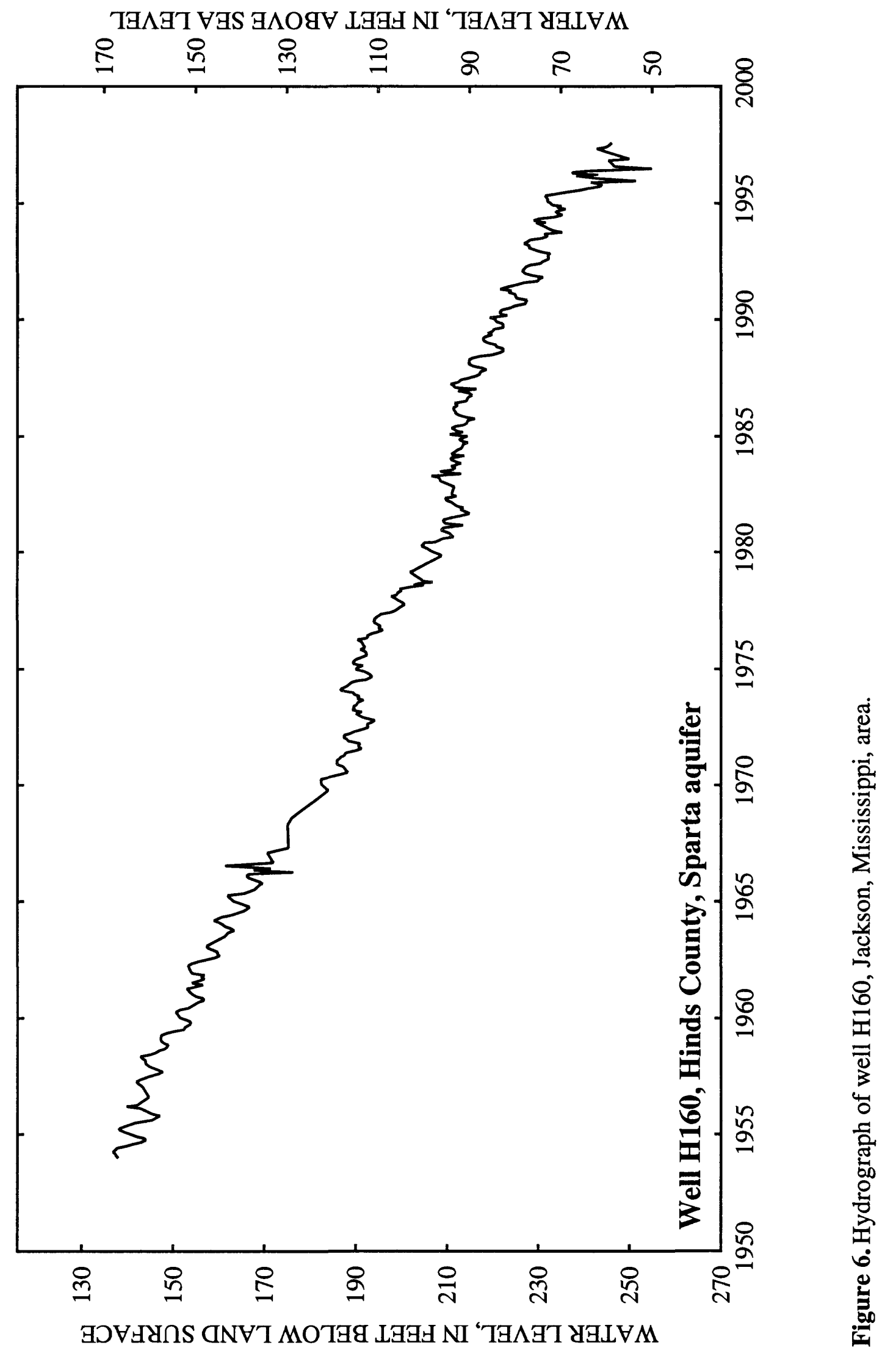


T

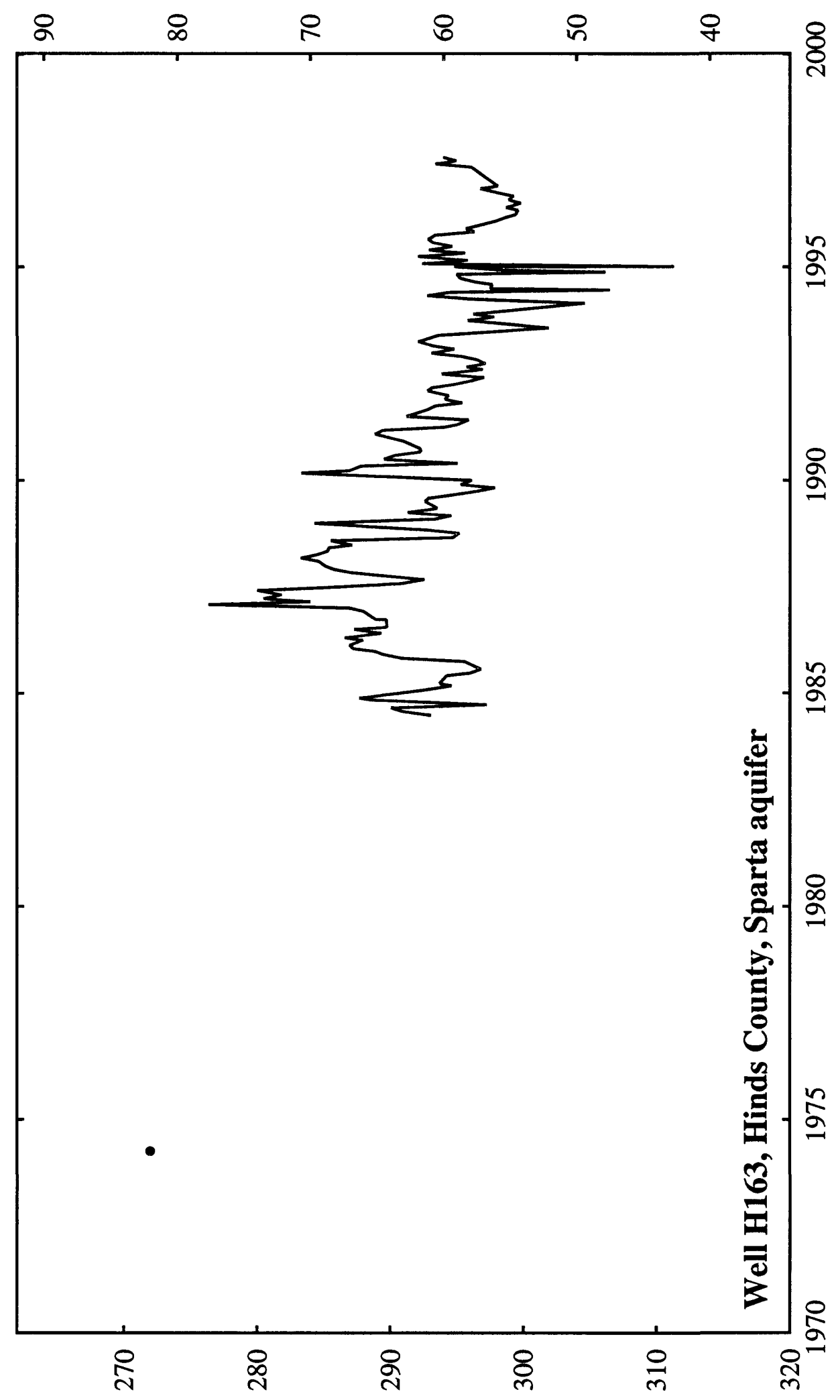

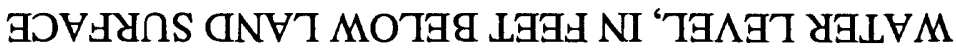




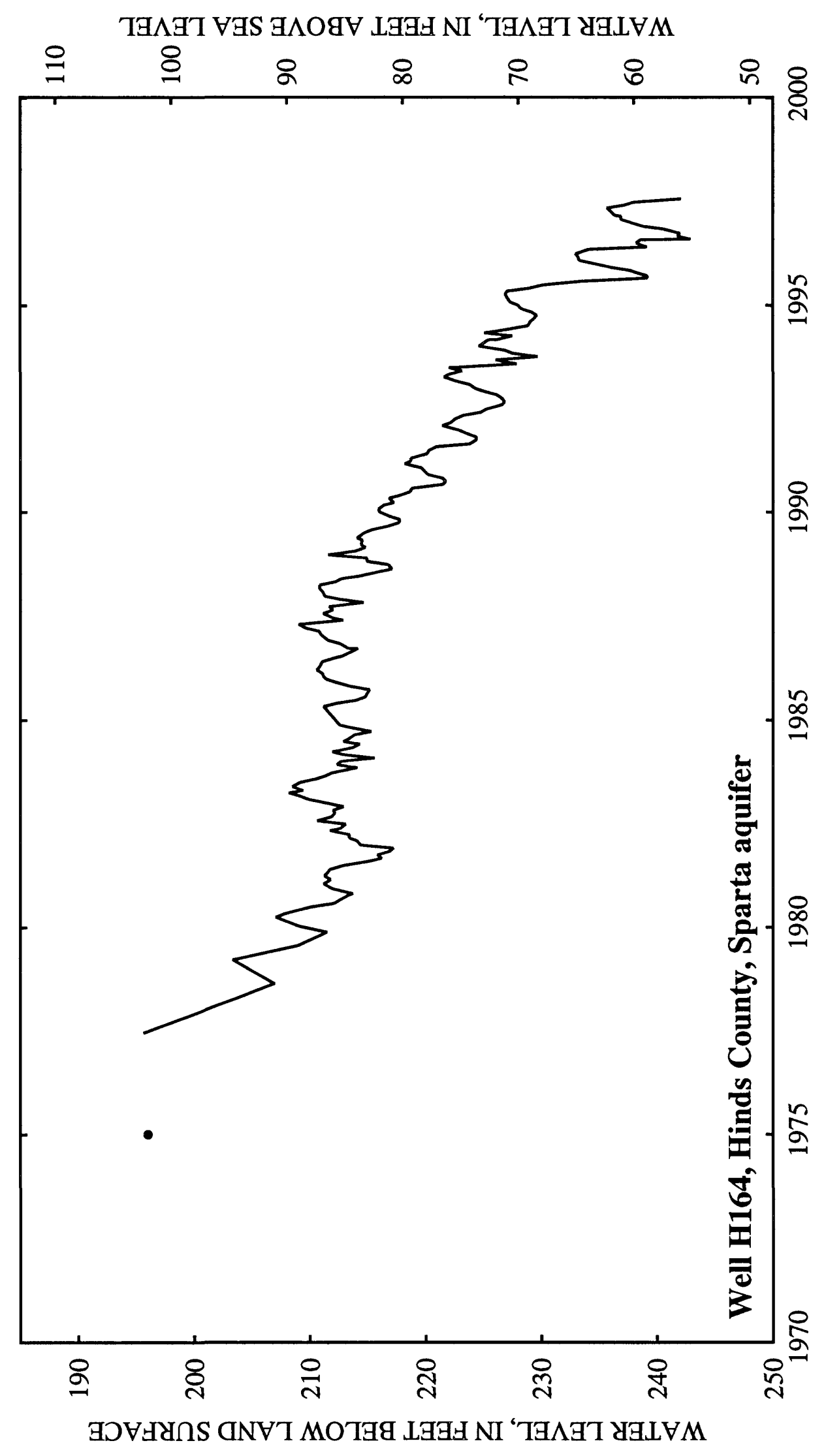

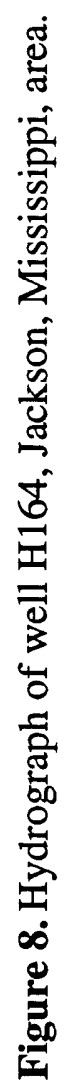




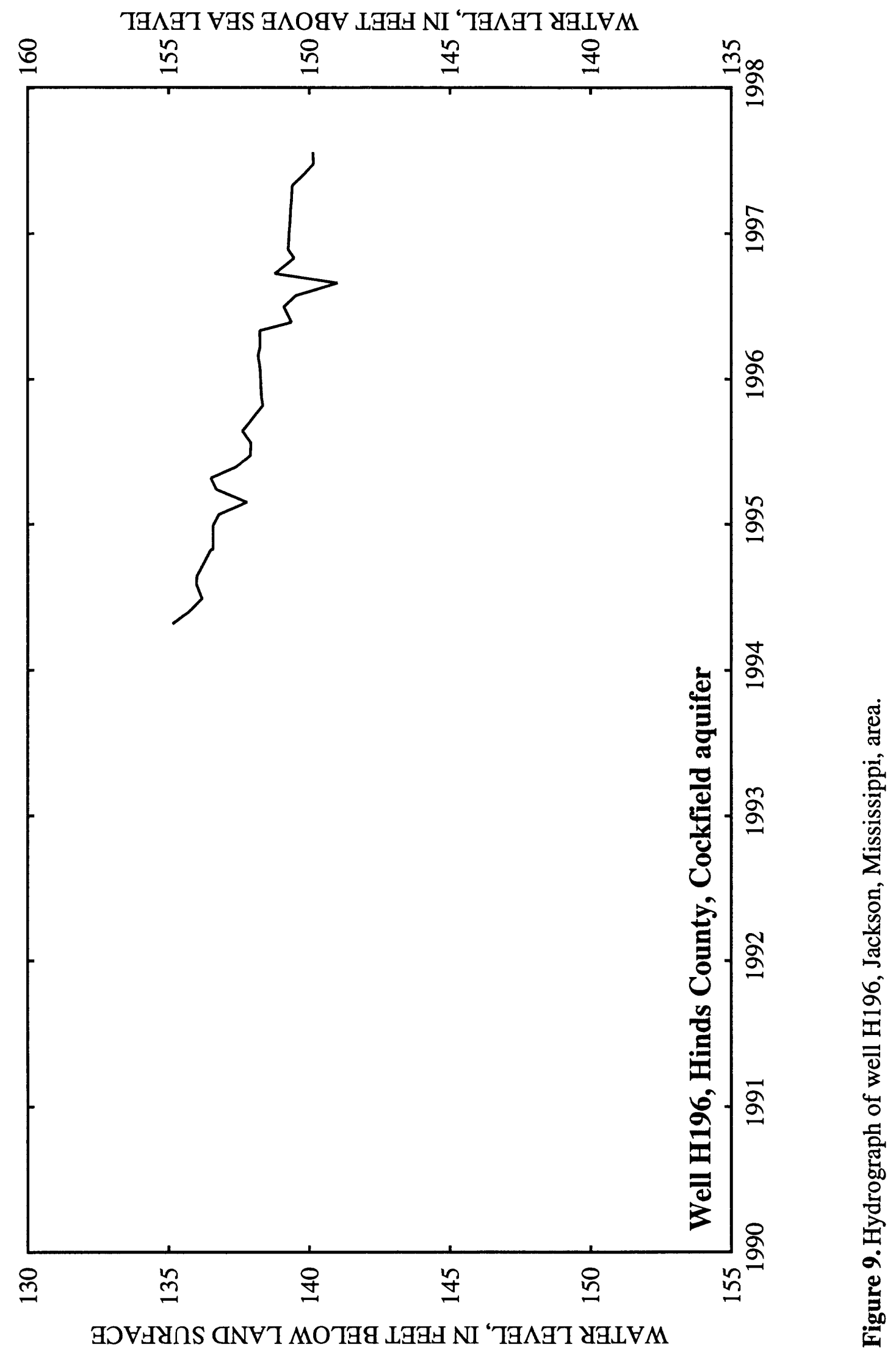




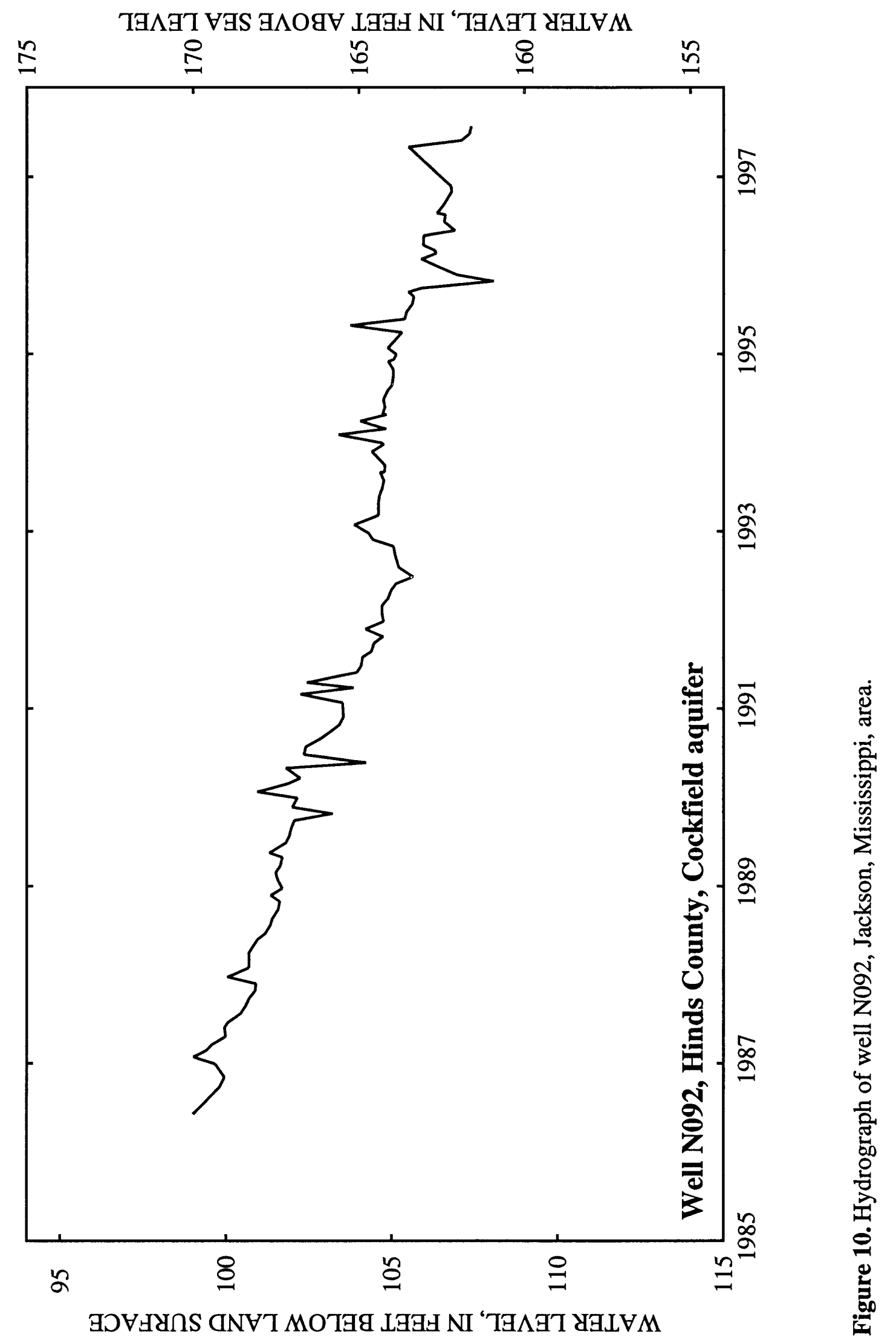




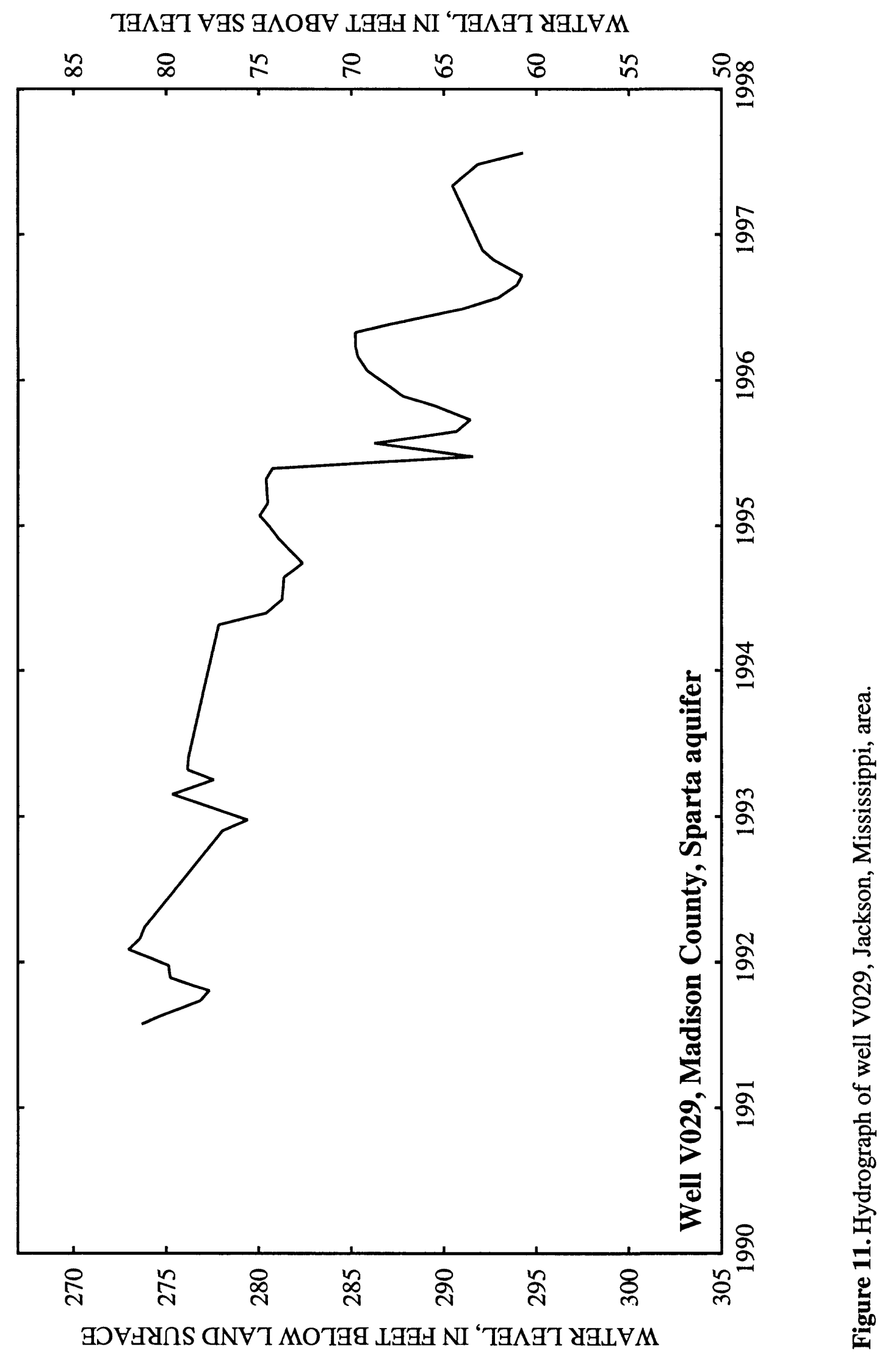




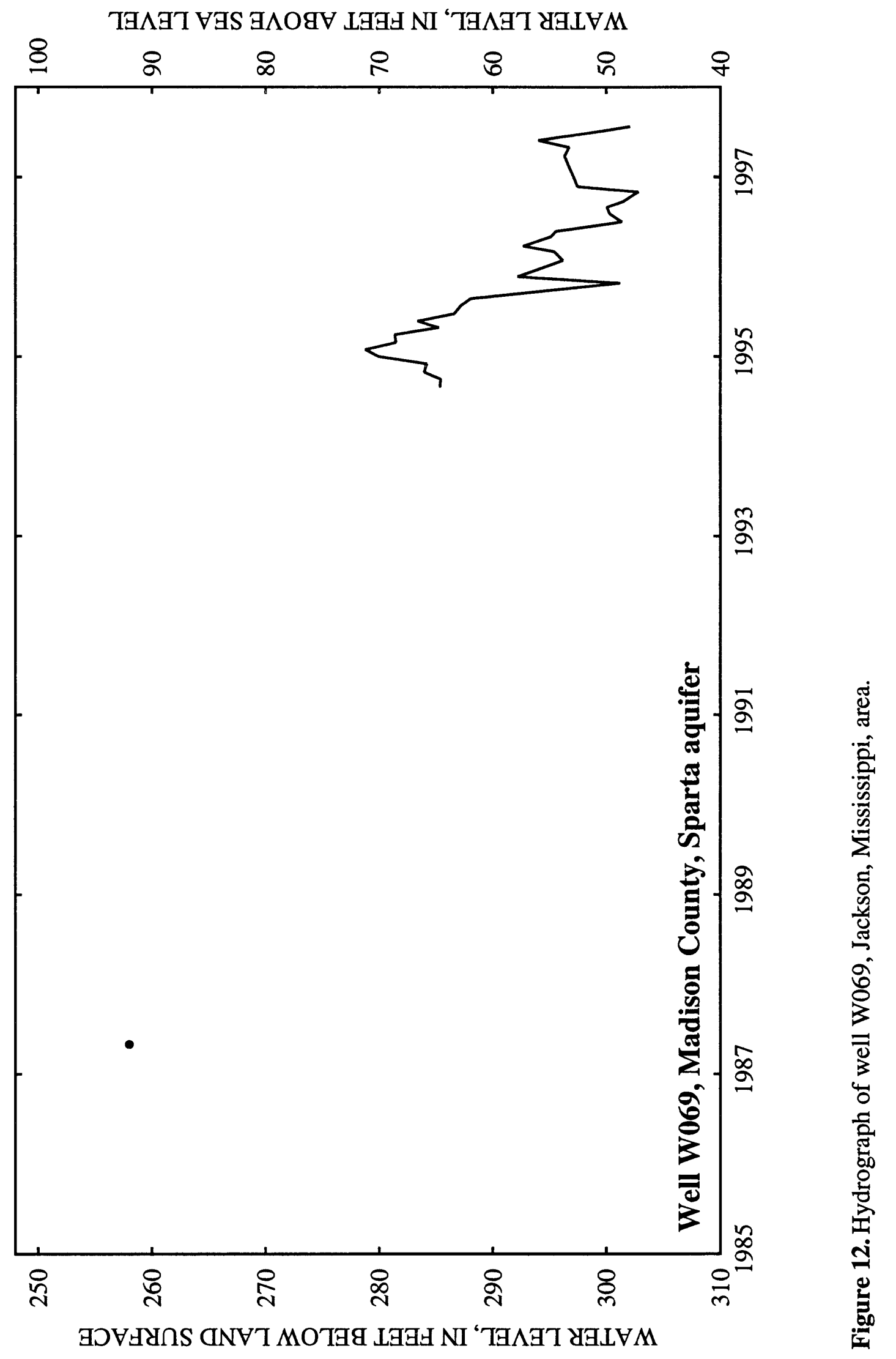


ㅇํㅇ유용 \& 8 \& 8 \& 8

B

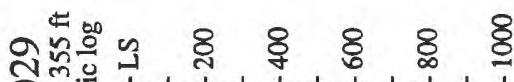

$S^{\circ}$ "I.

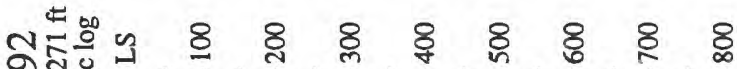

Z

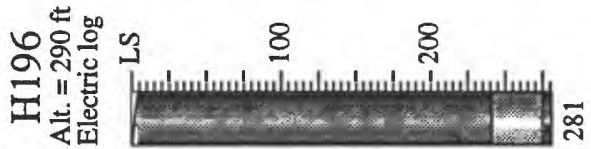

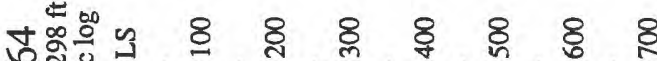

I

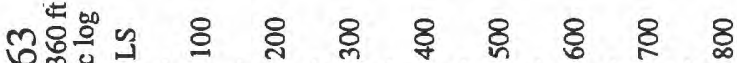

II.

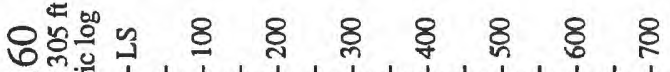

E

no

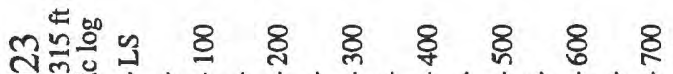

II

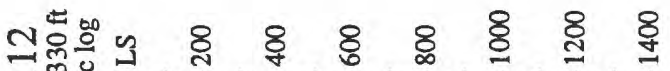

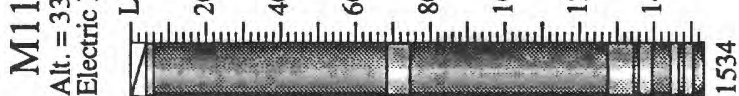

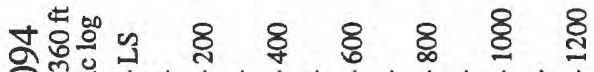

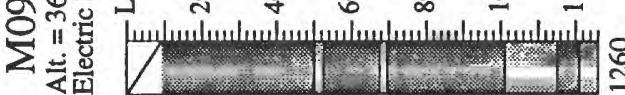

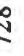

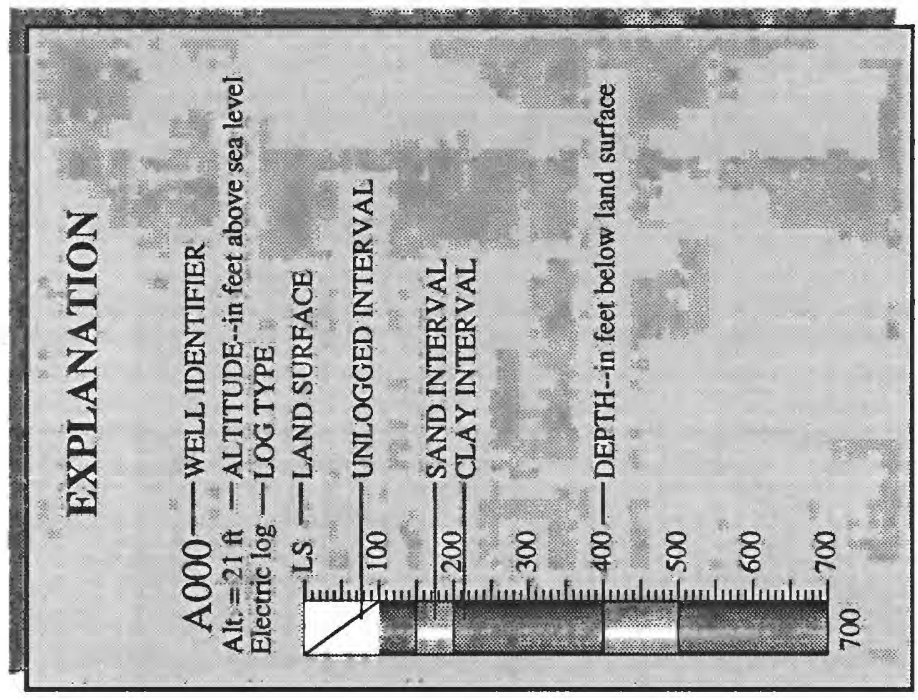

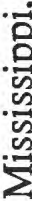

ำ

in

O

$\overline{1}$

7

迹

눈

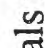

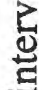

空

롫 